\title{
Impact of The Microbial Suppression by Using The Brown Alga Dictyota dichotoma Extract
}

\author{
Ibraheem B.M. Ibraheem, N. Abdel-Raouf, H.M. Mohamed", R. Yehia ${ }^{\#}$ and S.M. \\ Hamed $^{* *}$ \\ Botany \& Microbiology Department; 'Zoology Department, Faculty of Science, Beni- \\ Suef University, Beni-Suef, 62514 and ${ }^{* *}$ Soil Microbiology Department, Soils, Water
}

\begin{abstract}
TN THIS CONTEXT the brown alga Dictyota dichotoma isolated from Hurghada Sea-Shore, Red-Sea coast, Egypt (June 2015) was screened for its antimicrobial bioactivity. A laboratory experiment was conducted to test activity of ethanol extract of the brown alga Dictyota dichotoma against three types of Gram- positive and six of Gram-negative bacteria, and one type of fungi. Ethanol extract was selected for this study by using different concentrations (100, $200,300,400 \mathrm{mg}$ ) of alga extracts. Result revealed that the alga ethanolic extract exhibited high suppression activity against all tested pathogens. HPLC analysis of the chemical composition of algal extract was detect the presence of high amount of certain ingredients such as Flavonoids (Acacetin, Luteo.6-arabinose8-glucose, Naringin, Hespirtin, Rosmarinic and Naringenin by 3448.407, 453.209, 396.107, 387.429, 213.689 and 207.17 ppm, respectively) and Phenols (Benzoic, E-Vanillic, Pyrogallol, Catechein, Salycilic and Ellagic by 1075, 912, 785, 628 and $357 \mathrm{ppm}$, respectively). The present finding revealed that the tested alga can be used as possible natural source of active ingredients.
\end{abstract}

Key words: Dictyota dichotoma, Antimicrobial activity, HPLC analysis .

\section{Introduction}

The permanent uses of familiar antibiotics cause drug resistant pathogenic strains. Improvement of the resistant bacteria is globally deemed as main medical problem, thus initiate bighazard for human society (Neu, 1992). This has enhance a search for novel class of antibacterial materials from natural sources. Natural products are considered a significant source of therapeutic factors against bacterial and fungal diseases, cancer, lipid disturbances and immunomodulation (Haroun et al., 1995; Shridhar et al., 2009; Clardy \& Walsh, 2004; Cragg et al., 1997; Voidarou et al., 2011; Elsayed et al., 2012 and Abdel-Raouf et al., 2015a).

Marine algae are widely distributed along the Egyptian and Red-Seashore (Haroun et al., 1995; Mohamed et al., 2006 and Ibraheem et al., 2014). Marine algae are potential sources of bioactive secondary metabolites with possibility for use in the development of recent pharmaceutical agents (Abdel-Raouf et al., 2008; Abedin \&Taha., 2008; EL-Gamal, 2010 and AL-Saif et al., 2014) and various of these compounds have been confirmed to possess desirable biological activities (Faulkner, 2002; Ibraheem et al., 2008 and Abdel-Raouf et al., 2015b). Marine algae were announced to produce a wide diversity of bioactive secondary metabolites as antimicrobial, antifeedant, antiparasitic and cytotoxic agents and the bioactive substances inclusive alkaloids, polyketides, cyclicpeptide, quinines, glycerols, lipids, polysaccharide, phlorotannins, diterpenoids and sterols (Cabrita et al., 2010). Hence they have drawn major concern recently (Al-Haj et et al., 2009; Bazes et al., 2009; Vallinayagam et al., 2009; Cabrita et et al., 2010 and Ibraheem et al., 2012). Phaeophyceae have high amounts of polyphenols with a basic building block of 1,3,5-trihydroxybenzene (phloroglucinol) and were examined as a bioresource of polyphenols, biopolymers and bio-products.

Dictyota species are the optimal studied sources of secondary metabolites and the ecological purpose and biological activities of these compounds are deeply studied (Viano et al.,

"Corresponding author Rehab Yehia Fessehy, Botany and Microbiology Department, Faculty of Science, Beni-Suef University. email: rehab.yahia55@gmail.com, 
2009; Rasher \& Hay., 2010; Rasher et al., 2011 and Othmani et al., 2014). Dictyota dichotoma become increasingly common due to its rising economic significance as a source of diterpenes (Gupta \& Abu-Ghannam., 2011) and polyunsaturated fatty acids (Pereira et al,. 2012) and have possibility in biosorption of heavy metals (Laib \& Leghouchi, 2012 and Hannachi et al., 2015). Dictyota sp. is particularly rich in bioactive terpenes (Viano et al., 2009; Othmani et al., 2014 and Da Gama et al., 2014) of which some have an established potential as anti-fouling coatings, algicidal (Kim et al., 2006), anti-bacterial (Enoki et al., 1983), anti-fungal (Tringali et al., 1986) and molluscicidal activity (Tringali et al., 1986 and Barbosa et al., 2007). Antibacterial compounds have been isolated from marine resources but some of these do not show activity against Gram-negative bacteria (Morton et al., 1998 and Correa et al., 2011). Therefore, it is worthwhile to search for such compounds from marine resources showing potent antibacterial activity against human pathogenic bacteria. Subsequently, in present study we have screened the ethanolic extract of Dictyota dichotoma as antagonistic agent against some Gram positive and Gram negative bacteria, as well as HPLC analysis of the ethanolic extract has been characterized in order to find alternative drugs and promising source of pharmaceutical agents.

\section{Materials and Methods}

\section{Studied area}

The investigated area extends along Hurghada coast on Red-Sea, Egypt (Fig. 1). Safaga city located in the west coastal area of Red Sea shore between longitude $34^{\circ} 17^{\circ} \mathrm{E}$ and latitude $26^{\circ} 06^{\circ} \mathrm{N}$..

\section{Algal collection and preparation}

Dictyota dichotoma was collected on April (2015) from Safaga coastal along the Red Sea, Egypt, and identified according to Aleem (1993) and Coppejans et al. (2009). Samples were cleaned with seawater to remove impurities and transported to the laboratory in sterile polythene bags. In the laboratory, samples were rinsed with tap water and were shade dried, cut into small pieces and powdered in a mixer grinder until a fine powder was obtained (Chiheb et al., 2009).

\section{Ethanolic extraction of Dictyota dichotoma}

The dried material of Dictyota dichotoma was mixed with ethanol $(1: 50, \mathrm{w} / \mathrm{v})$ and placed into the Soxhlet apparatus (Fig. 2). Extraction solvent was evaporated under vacuum and stored in $-20^{\circ} \mathrm{C}$ until used.

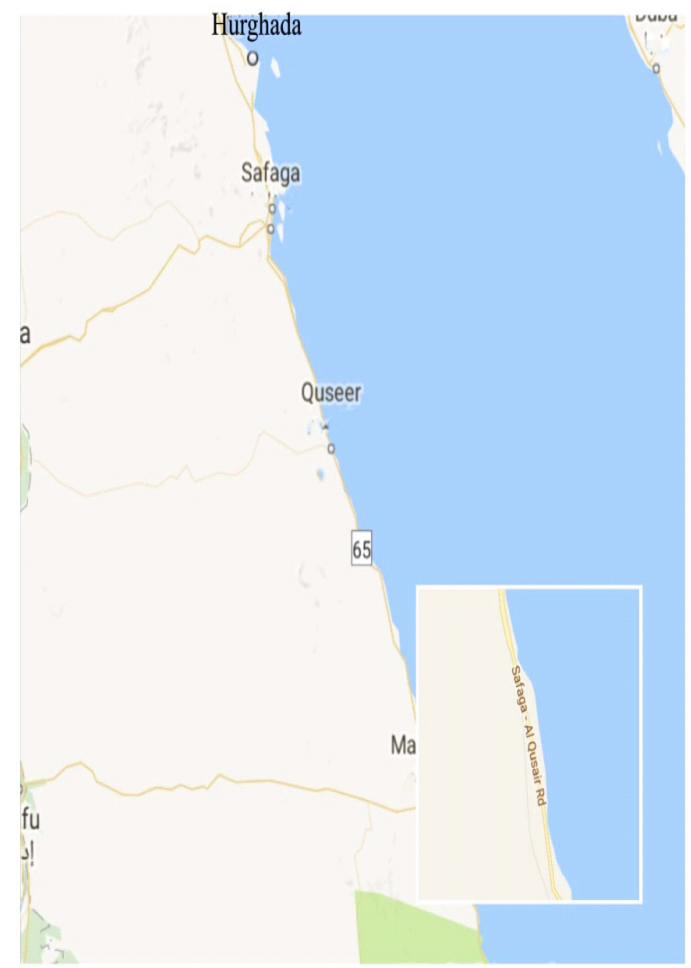

Fig. 1. Location of study area.

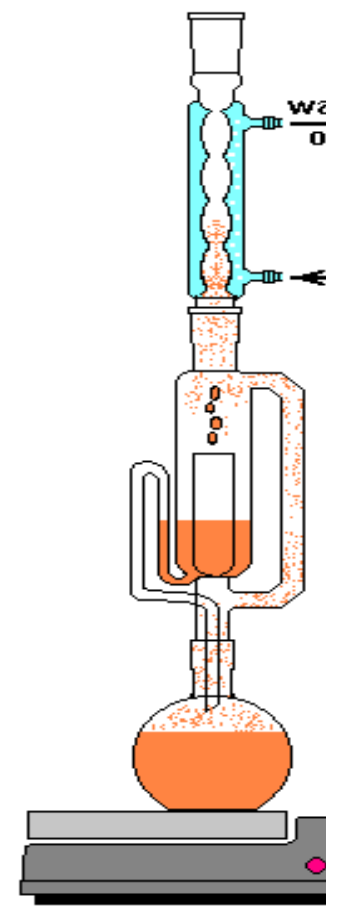

Fig. 2. Soxhlet extractor of marine alga Dictyota dichotoma. 
Antimicrobial activity of the studied algae

Gram positive

For testing the anti-Gram positive activity, the following isolates including Bacillus subtilis (RCMB 01001 69-3), Staphylococcus aureus (RCMB 010027), Micrococcus luteus (RCMB 01001 76-9) were selected.

\section{Gram negative}

For testing the anti-Gram negative activity, the following isolates including Escherichia coli (RCMB 01002 52-6), Pseudomonas aeruginosa (RCMB 01002 43-5), Serratia marcescens (RCMB 01002 75b-8), Salmonella typhi (RCMB 01002 15-4), Vibrio sp. and Aeromonas hydrophila were selected.

Fungi

For antifungal activity, the unicellular Candida albicans (RCMB 05036), was used for this purpose.

Antimicrobial activity by disc diffusion method

In the present study, antibacterial activity was determined against the above bacteria using the paper disc assay method (El-Masry et al., 2000). Whatman No. 3 filter paper disc of 6-mm diameter was sterilized by autoclaving for 15 $\min$ at $121{ }^{\circ} \mathrm{C}$. The sterile discs were saturated by $20 \mu 1$ with different concentrations $(100,200$, 300 and $400 \mathrm{mg} / \mathrm{ml}$ ) to become loaded by 2, 4, 6 and $8 \mathrm{mg}$ for each disc, respectively. Agar plates were surface inoculated uniformly from the broth culture of the tested microorganisms. In all cases, the concentration was approximately $1.2 \times 10^{8} \mathrm{CFU} / \mathrm{ml}$. The impregnated discs were placed on the Muller Hinton medium suitably spaced apart and the plates were incubated at $37^{\circ} \mathrm{C}$ for $24 \mathrm{~h}$. Ethanol was used as a negative controlwhile commercial antibiotic discs (Ampcillin $10 \mathrm{mg} / \mathrm{disc}$ ) were used as a positive control. The above procedure is allowed for fungal assays but expects the potato dextrose agar media instead of nutrient agar media. The plates were incubated at $25^{\circ} \mathrm{C}$ for $48 \mathrm{~h}$ in the case of investigated fungus species. The diameter of inhibition halos measured in millimeter. All the assays were carried out in triplicate (Fig. 3).
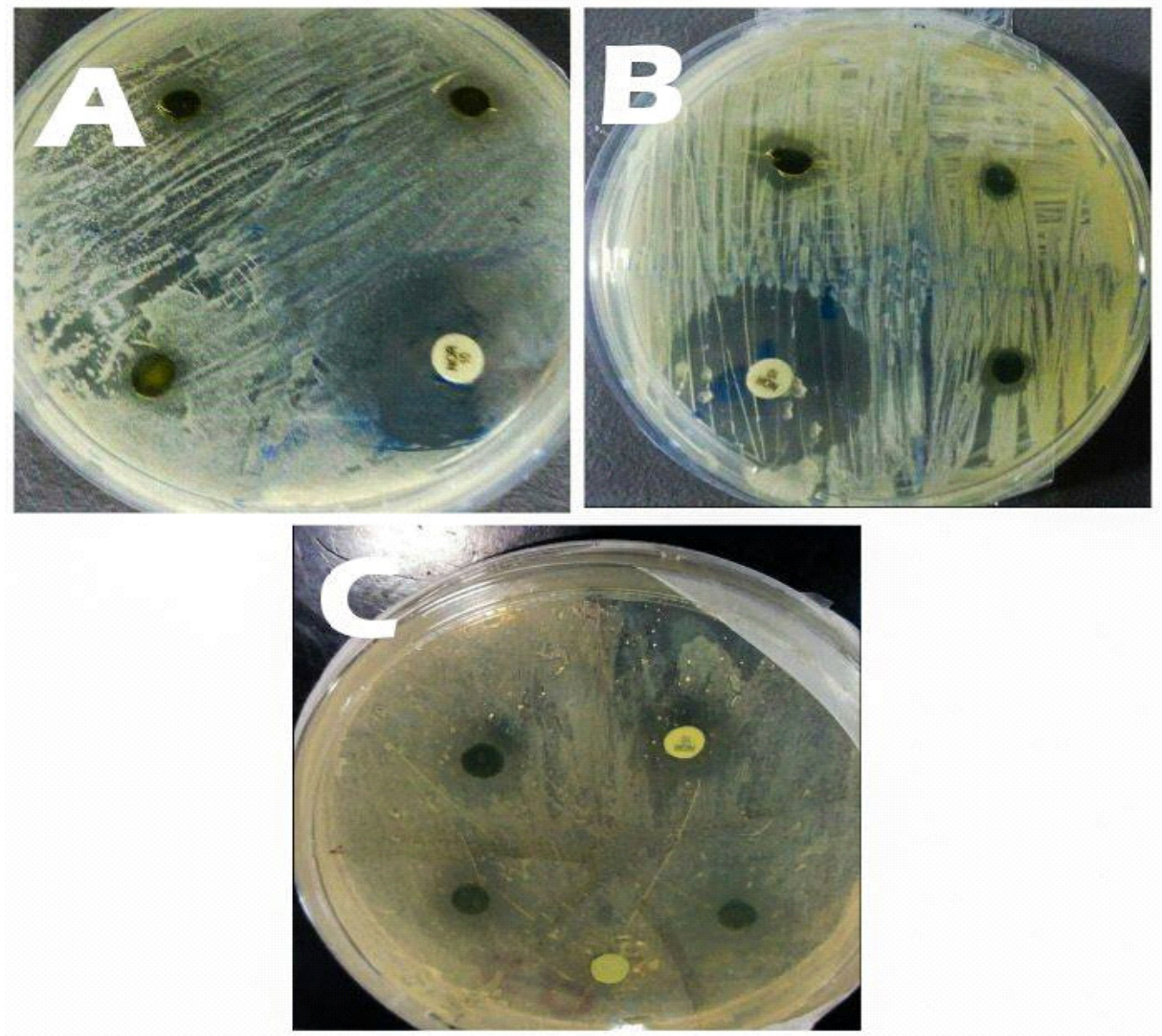

Fig. 3. Inhibition zones obtained by the ethanolic extract of Dictyota dichotoma against Staphylococcus aureus (A), Pseudomonas aeuroginosa (B), Escherichia coli (C). 
Chemical analysis of Dictyota dichotoma HPLC analyses of flavonoid, phenolic and polysaccharides compounds

Flavonoid, phenolic and polysaccharides in the ethanolic extract of Dictyota dichotoma were determined according to method described by Goupy et al. (1999) and Zielinski et al. (2014). The detection were conducted using high performance liquid chromatography (HPLC Agilent 1200 series) equipped with Quaternary pump, Auto sampler, column compartment set at $35^{\circ} \mathrm{C}$, multi wavelength detector set at $330 \mathrm{~nm}, 280 \mathrm{~nm}$.

\section{Statistical analysis}

All results are presented as the mean \pm SD. Statistical analysis was carried out by using one-way ANOVA (Duncan, 1957). Statistical significance was considered at $p<0.05$.

\section{$\underline{\text { Results }}$}

Antimicrobial essay

Ethanolic extract of the brown alga Dictyota dichotoma was assayed for antibacterial \& antifungal activity by using agar diffusion method (Table1). Data revealed that, Dictyota dichotoma extracts demonstrated a good antimicrobial activity against all gram-positive and gram-negative pathogenic bacteria. It can be seen that the ethanolic extract in concentration of $10 \mathrm{mg} /$ disc gave the highest inhibition zone (16 $\mathrm{mm}$ ) against Bacillus subtilis. Moreover, it gives a moderate inhibition activity ( 9 to $12 \mathrm{~mm}$ ) against the other test organisms.

\section{HPLC analysis of Dictyota dichotoma ethanolic} extract

Ethanolic extraction of Dictyota dichotoma was subjected to HPLC for the identification of constituents present in the alga extract which suggest being the cause of antimicrobial activity in Dictyota dichotoma. The quantitative HPLC analysis of ethanol extract of Dictyota dichotoma displayed three major compounds flavonoids, phenols and saccharide which were estimated. HPLC analysis of the flavonoid constituents of the alga ethanolic extract exhibited a presence of 19 compounds (Table 2). Acacetin (3448.407 ppm), followed by Luteo.6-arabinose8-glucose, Naringin, Hespirtin, Rosmarinic and Naringenin by $453.209,396.10,387.429,213.689$ and 207.173 ppm, respectively. On the other hand, the remain flavonoid contents were represented by moderately or less amounts.

TABLE 1. Antimicrobial activities of the Dictyota dichotoma ethanolic extract (inhibition of growth expressed as mean \pm SD).

\begin{tabular}{|c|c|c|c|c|c|c|}
\hline \multirow{4}{*}{ Pathogen } & \multicolumn{6}{|c|}{ Diameter of inhibition zone, mean \pm SD } \\
\hline & \multicolumn{4}{|c|}{$\begin{array}{c}\text { Dictyotadichotomaconcentrations } \mathrm{mg} / \mathrm{disc} \\
\text { (Tested sample) }\end{array}$} & \multirow{3}{*}{$\begin{array}{l}\begin{array}{c}\text { Ampcillin(positive) } \\
\text { control }\end{array} \\
10 \\
\mathrm{mg} / \text { disc }\end{array}$} & \multirow{3}{*}{$\begin{array}{c}\begin{array}{c}\text { Ethanol } \\
\text { (negative) } \\
\text { control }\end{array} \\
20 \\
\mu \mathrm{l} / \text { disc }\end{array}$} \\
\hline & 2 & 4 & 6 & 8 & & \\
\hline & mg/ disc & mg/ disc & mg/ disc & mg/ disc & & \\
\hline \multicolumn{7}{|l|}{ Gram positive bacteria } \\
\hline Staphylococcus aureus & $7.50 \pm 0.5$ & $8.00 \pm 1.00$ & $9.00 \pm 1.00$ & $12.40 \pm 0.57$ & $30.00 \pm 01.00$ & 00 \\
\hline Micrococcus luteus & $9.00 \pm 1.00$ & $10.00 \pm 1.00$ & $10.00 \pm 1.00$ & $12.30 \pm 0.57$ & $35.00 \pm 01.00$ & 00 \\
\hline Bacillus subtilis & $11.00 \pm 1.00$ & $12.00 \pm 1.00$ & $15.00 \pm 1.00$ & $16.00 \pm 1.30$ & $25.00 \pm 12.66$ & 00 \\
\hline \multicolumn{7}{|l|}{ Gram negative bacteria } \\
\hline Serratiamarcescens & $06.33 \pm 0.57$ & $8.00 \pm 1.00$ & $10.00 \pm 1.00$ & $11.30 \pm 0.57$ & $30.00 \pm 01.00$ & 00 \\
\hline Salmonella sp. & $08.80 \pm 0.76$ & $10.00 \pm 1.00$ & $10.60 \pm 1.15$ & $09.66 \pm 2.50$ & $25.00 \pm 05.00$ & 00 \\
\hline Vibrio sp. & $08.00 \pm 1.00$ & $08.50 \pm 0.50$ & $9.00 \pm 1.00$ & $10.50 \pm 0.50$ & $28.00 \pm 15.66$ & 00 \\
\hline Aeromonashydrophila & $07.50 \pm 1.00$ & $08.00 \pm 1.00$ & $08.00 \pm 1.00$ & $08.00 \pm 1.00$ & $25.00 \pm 1.50$ & 00 \\
\hline Pseudomonas aeuroginosa & $07.00 \pm 1.00$ & $10.00 \pm 1.00$ & $11.30 \pm 0.57$ & $11.60 \pm 1.50$ & $35.00 \pm 02.8$ & 00 \\
\hline Escherichia coli & ND & ND & ND & $08.60 \pm 1.15$ & $12.00 \pm 01.00$ & 00 \\
\hline \multicolumn{7}{|l|}{ Fungi } \\
\hline Candida albicans & $10.00 \pm 1.00$ & $11.00 \pm 1.00$ & $11.00 \pm 1.00$ & $12.00 \pm 1.00$ & $27.00 \pm 01.15$ & 00 \\
\hline
\end{tabular}

Egypt. J. Bot. (2017) 
TABLE 2. HPLC analysis for flavonoid contents ofe thanolic extract of Dictyota di-chotoma isolated from Safaga Sea-shore during April to June 2015.

\begin{tabular}{lc}
\hline Flavonoids contents & ppm \\
\hline Luteo.6-arabinose8-glucose & $\mathbf{4 5 3 . 2 0 9}$ \\
Apig.6-rhamnose8-glucose & 119.520 \\
Apig.6-glucose8-rhamnose & 74.300 \\
Naringin & $\mathbf{3 9 6 . 1 0 7}$ \\
Luteo.7-glucose & 52.094 \\
Hespirdin & 51.514 \\
Rutin & 20.226 \\
Quercetin-3-o-glucoside & 16.206 \\
Rosmarinic & $\mathbf{2 1 3 . 6 8 9}$ \\
Apig.7-o-neohespiroside & 29.945 \\
Kamp3,7-dirhamoside & 120.396 \\
Quercetrin & 35.493 \\
Quercitin & 95.927 \\
Naringenin & $\mathbf{2 0 7 . 1 7 3}$ \\
Hespirtin & $\mathbf{3 8 7 . 4 2 9}$ \\
Kampferol & 176.258 \\
Rhamnetin & 113.216 \\
Apigenin & 15.101 \\
Acacetin & $\mathbf{3 4 4 8 . 4 0 7}$ \\
\hline
\end{tabular}

With respect to the HPLC analysis of the phenolic contents of the ethanolic extract of Dictyota dichotoma (Table 3), the recorded data indicated the presence of twenty two phenolic compounds in different concentrations. From these compounds, Benzoic, E-Vanillic, Pyrogallol, Catechein and Salycilic in high amount reached 1323, 1075, 912, 785 and 628 ppm, respectively.

Additionally, HPLC analysis of the saccharides contents of the ethanolic extract of Dictyota dichotoma (Table 4) revealed the presence of relatively low percentage of mono, di- and poly saccharides in the crude extract.

\section{Discussion}

According to the present data, both Gram $(+)$ and Gram (-) bacteria exhibited a sensitive effect to the alga crude extract, it means that Dictyota dichotoma contains a specific natural compounds display strong potential to penetrate the complex structure of the Gram (+) and Gram (-) bacterial cell wall. However, the Gram $(+)$ strains were exhibited more sensitivity to the alga extract than Gram (-) bacteria. This was agree with reports of Strik et al. (2007) and Salem et al. (2011) who suggest that algal extract were generally more effective against Gram $(+)$ than Gram (-) bacteria. The high sensitivity in Grampositive bacteria may be attributed to the lack of the outer membrane (lipopolysaccharide layer) which is present in Gram-negative bacteria (Nikaido, 2003). The limited susceptibility in Gram-negative bacteria could be attributed to the limited outer membrane permeability and presence of porins in the membrane which narrows penetration of the extract (Delcour, 2009 and Nikaido., 2003).

TABLE 3. HPLC analysis for phenolic contents of ethanolic extract of Dictyota dichotoma isolated from Safaga Sea-shore during April to June 2015.

\begin{tabular}{lc}
\hline Phenolic contents & Ppm \\
\hline Pyrogallol & $\mathbf{9 1 2}$ \\
Gallic & 89.9 \\
4-Amino-benzoic & 155 \\
Protocatchuic & 16.2 \\
Catechein & $\mathbf{7 8 5}$ \\
Catechol & 14.9 \\
Chlorogenic & 185 \\
Epicatechein & 33 \\
P-OH-benzoic & 130 \\
Caffeine & 97.1 \\
Vanillic & 195 \\
Caffeic & 4.11 \\
P-coumaric & 52.8 \\
Ferulic & 124 \\
Iso-Ferulic & 100 \\
E-Vanillic & $\mathbf{1 0 7 5}$ \\
Benzoic & $\mathbf{1 3 2 3}$ \\
Ellagic & $\mathbf{3 5 7}$ \\
Coumarin & 37.9 \\
3,4,5-methoxy- & 167 \\
Sinnamic & $\mathbf{6 2 8}$ \\
Cinnamic & 8.2 \\
\hline & \\
\hline &
\end{tabular}


TABLE 4. HPLC analysis for saccharides contents of ethanolic extract of Dictyota dichotoma isolated from Safaga Sea-shore during April to June 2015.

\begin{tabular}{|c|c|}
\hline Saccharides contents & $\%$ \\
\hline \multicolumn{2}{|c|}{ - $\quad$ Free saccharides: } \\
\hline Glucuronic & 0.05 \\
\hline Stachyose & 0.26 \\
\hline Sucrose & 0.07 \\
\hline Maltose & 0.04 \\
\hline Glucose & 0.04 \\
\hline Xylose & 0.05 \\
\hline Galactose & 0.04 \\
\hline Rhaminose & 0.06 \\
\hline Fructose & 0.05 \\
\hline Manitol & 0.01 \\
\hline Sorbitol & 0.03 \\
\hline \multicolumn{2}{|c|}{ - $\quad$ Saccharides after hydrolysis : } \\
\hline Glucuronic & 0.20 \\
\hline Galacturonic & 0.44 \\
\hline Sucrose & 0.19 \\
\hline Glucose & 0.21 \\
\hline Xylose & 0.35 \\
\hline Galactose & 0.20 \\
\hline Mannose & 0.17 \\
\hline Fructose & 0.09 \\
\hline Manitol & 0.09 \\
\hline Sorbitol & 0.05 \\
\hline
\end{tabular}

It is clear that this anti-bacterial activity is not as effective as their 'gold' standard (ampicillin) counterparts. This could be due to the fact that antibiotics such as ampicillin, penetrate the outer membrane of (primarily Gram-negative) bacteria via porins (James et al., 2009) and then act as a competitive inhibitor of transpeptidase needed by the bacterium to make a cell wall, an effect that ultimately leads to cell lysis and an overall reduced ability of the pathogens to successfully replicate. In contrast, Dictyota dichotoma extracts is thought to impart anti-microbial effects possibly via the induction of changes in the cell membranes of the targeted pathogen organisms, with alterations in the cell envelope causing impaired regulation of osmolality and ultimately cell death. Notwithstanding, this is a preliminary study, hence detailed investigations to identify the compositions of each extract is necessary for the recognition of major marine algae constituents that could serve as strong antimicrobial compounds (Sakineh et al., 2016).

HPLC analysis of the chemical composition of algal extract was detect the presence of high amount of certain ingredients such as Flavonoids (Acacetin, Luteo.6-arabinose8-glucose, Naringin, Hespirtin, Rosmarinic and Naringenin by $3448.407,453.209$, 396.107, 387.429, 213.689 and $207.17 \mathrm{ppm}$, respectively) and Phenols (Benzoic, E-Vanillic, Pyrogallol, Catechein, Salycilic and Ellagic by 1075, 912, 785, 628 and 357 ppm, respectively). Flavonoids have aroused considerable interest recently because of their potential beneficial effects on human health in fighting disease (Deyab et al., 2016). In general, phenolic compounds possessed specific physical, chemical and biological activities that make them useful as drugs. Phenolics were also responsible for the antimicrobial, antiinflammatory, anti-viral, anticancer actions (Aliyu, et al., 2009). In this respect (AL-Saif et al., 2014) reported that macroalgae produce a wide variety of chemically active metabolites including alkaloids, polyketides, cyclic peptide, polysaccharide, phlorotannins, diterpenoids, sterols, quinones, lipids and glycerols that have a broad range of biological activities. Also (Priyadharshini et al., 2011) have reported that seaweeds are an excellent source of components such as polysaccharides, tannins, flavonoids, phenolic acids, bromophenols, and carotenoids have exhibited different biological activities.

\section{Conclusion}

In conclusion, the results of the present investigation indicated that the brown alga Dictyota dichotoma has biologically active compounds which are effective in inhibiting the growth of the pathogenic bacteria and fungi. Further the RedSea marine environment has potential to return pharmaceutically useful marine algae which can be harnessed for the development of drugs for use in management of human pathogens, and many human degenerative diseases. 


\section{Reference}

Abdel-Raouf, N., Ibraheem, I.B.M., Abdel-Hameed, M.S. and El-Yamany, K.N. (2008) Evaluation of antibacterial, antifungal and antiviral activities of ten marine macroalgae from Red Sea, Egypt. Egypt. J. Biotechnol. 29, 157-172.

Abdel-Raouf, N., Al-Enazi, N.M., Al-Homaidan, A.A., Ibraheem, I.B.M., Al-Othman, M.R. and Hatamleh, A. (2015a) Antibacterial $\beta$-amyrin isolated from Laurencia microcladia. Arabian Journal of Chemistry, 8, 1, 32-37.

Abdel-Raouf, N., Al-Enazi, N.M., Ibraheem, I.B.M. and Al-Harbie, R.M. (2015b) Antibacterial and anti-hyperlipidemic activities of the brown alga Hormophysa cuneiformis from Ad Dammam Seashore. Journal of Applied Pharmaceutical Science, 5 (8), 114-125

Abedin, R.M.A. and Taha, H.M. (2008) Antibacterial and antifungal activity of cyanobacteria and green microalgae evaluation of medium components by Plackett-Burman design for antimicrobial activity of Spirulina plastensis. Global J. Biotechnol.Biochem. 3(1), 22-31.

Aleem, A.A. (1993) "The Marine Algae of Alexandria". Egypt. Egyptian Books House.

Al-Haj, N., Mashan, N., Shamsudin, M., Mohamed, H., Vairappan, C. and Seakawi, Z. (2009) Antibacterial activity in marine algae Eucheuma denticulatum against Staphylo-coccus aureus and Streptococcus pyogenes. Res. J. Biol. Sci. 4, 519-524.

Aliyu, A.B., Musa, A.M. Sallau, M.S. and Oyewale, A.O. (2009) Proximate composition, mineral elements and anti-nutritional factors of Anisopus mannii N.E.Br.(Asclepiadaceae). Trends Appl. Sci. Res. 4(1), 68-72,

AL-Saif, S.S., Adbel-Raouf, N., E1-Wazanani, H.A. and Aref, I.A. (2014) Antibacterial substances from marine algae isolated from Jeddah Coast of Red Sea, Saudi Arabia. Saudi J. Biol. Sci. (21), 57-64.

Barbosa, J.P., Fleury, B.G., da Gama, B.A.P., Teixeira, V.L. and Pereira, R.C. (2007) Natural products as antifoulants in the Brazilian brown alga Dictyota pfaffii (Phaeophyta, Dictyotales). Biochem. Syst. Ecol. 35,549-553.
Bazes, A., Silkina, A., Douzenel, P., Fay, F., Kervarec, N., Morin, D., Berge, J. and Bourgougnon, N. (2009) Investigation of the antifouling constituents from the brown alga Sargassum muticum (Yendo) fenshott. J. Appl. Phycol. 21 (4), 395-403.

Cabrita, M., Vale, C. and Rauter, A. (2010) Halogenated compounds frommarine algae. Mar. Drugs 8, 2301-2317.

Chiheb, I., Riadi, H., Martinez-Lopez, J., Dominguez, S., Gomez, V.J., Bouziane, H. and Kadiri, M. (2009) Screening of antibacterial activity in marine green and brown macroalgae from the coast of Morocco. Afr. J. Biotechnol. 8, 12581262.

Clardy, J. and Walsh, C. (2004) Lessons from natural molecules. Nature, 432, 829-37.

Cragg, G., Newman, D. and Snader, K.(1997) Natural products in drug discovery and development. $J$. Nat. Prod. 60, 52-60.

Coppejans, E., Leliaert, F., Dargent, O., Gunasekara, K. and Clerck, O. (2009) "Srilanka Seaweeds. Methodologies and Field Guide to the Dominant Species". University of Ruhuna, Dept. of Botany, Matora, Srilanka. pp.1-265.

Correa, H., Aristizabal, F., Duque, C. and Kerr, R. (2011) Cytotoxic and antimicrobial activity of pseudopterosins and seco-pseudopterosins isolated from the octocoral Pseudopterogorgia elisabethae of San Andrés and Providencia Islands (Southwest Caribbean Sea). Mar. Drugs, 9, 334-44.

Cragg, G., Newman, D. and Snader, K. (1997) Natural products in drug discovery and development. $J$. Nat. Prod. 60, 52-60.

Da Gama, B.A.P., Plougerné, E. and Pereira, R.C. (2014) The antifouling defence mechanisms of marine macroalgae.Adv. Bot. Res.71, 413-440.

Delcour, A.H.(2009) Outer membrane permeability and antibiotic resistance. Biochimica et Biophysica Acta (BBA)-Proteins and Proteomics, 1794, 808-816.10.

Deyab, M., Elkatony, T. and Ward, F.(2016) Qualitative and quantitative analysis of phytochemical studies on brown seaweed, Dictyota dichotoma. International Journal of Engineering Development and Research (www.ijedr.org , 2016 IJEDR 4(2) ISSN: 2321 -9939. 
Duncan, B.D.(1957) Multiple range tests for correlated and heteroscedastic means. Biometrics, 13, 359-364.

EL-Gamal, A.A. (2010) Biological importance of marine algae. Saudi. Pharm. J. 18 (1), 1-33.

El-Masry, H.A., Fahmy, H.H. and Abdel-wahed, A.S.H. (2000) Synthesis and antimicrobial activity of some new benzimidazole derivatives. Molecules, 5,1429-1438.

Elsayed, K.N., Radwan, M.M., Hassan, S.H., Abdel-hameed, M.S., Ibraheem, I.B. and Ross, S.A. (2012) Phytochemical and biological studies on some Egyptian seaweeds. Nat. Prod. Commun. 7, 1209-1210.

Enoki, N., Tsuzuki, K., Omura, S., Ishida, R. and Matsumoto, T. (1983) New antimicrobial diterpenes, dictyol $\mathrm{F}$ and epidictyol $\mathrm{F}$, from the brownalga Dictyota dichotoma. Chem. Lett. 12, 1627-1630.

Faulkner, D.J. (2002) Marine natural products. Nat. Prod. Rep. 19, 1-48.

Goupy, P., Hugues, M., Boivin, P. and Amiot, M.J. (1999) Antioxidant composition and activity of barley (Hordeum vulgare) and malt extracts and of isolated phenolic compounds. J. Sci. Food Agric. 79,1625-1634.

Gupta, S. and Abu-Ghannam, N. (2011) Bioactive potential and possible health effects of edible brown seaweeds. Trends Food Sci. Technol. 22, 315-326.

Hannachi, Y., Rezgui, A., Dekhil, A.B. and Boubaker, T. (2015) Removal of cadmium (II) from aqueous solutions by biosorptionontothe brown macroalga (Dictyota dichotoma). Desalin Water Treat. 54, 1663-1673.

Haroun, B.M., Sharaf, A.M. and Ibrahim, B. (1995) Evaluation of natural productions in some common Egyptian marine algae. J. Union. Arab Biol. B, Botany, 2, 137-153

Ibraheem, I.B.M., Abdel-Raouf, N., Hammouda, O. and Abdel-Wahab, N. (2008) The potential for using culture filtrate of Chroococcus minutesas fungicidal agent against phytopathogenic Pythium sp. Egypt. J. Phycol. 9, 100-115.

Ibraheem, I.B.M., Alharbi, R. M., Abdel-Raouf, N. and
Al-Enazi, N.M. (2014) Contributions to the study of the marine algae inhabiting Umluj Seashore, Red Sea. Beni-Suef University. Journal of Basic and Applied Sciences, 3(4), 278-285.

Ibraheem, I.B.M., Neveen, N., Mohamed, S.A. and Khaled, E.Y. (2012) Antimicrobial and antiviral activities against new castle disease virus (NDV) from marine algae isolated from qusier and Marsaalam Seashore (Red Sea), Egypt. African Journal of Biotechnology, 11, 8332-8340.

James, C.E., Mahendran, K.R., Molitor, A., Bolla, J.M., Bessonov, A.N., Winterhalter, M. and Pages, J.M. (2009) How b-lactam antibiotics enter bacteria: a dialogue with the porins. Plos One, 4,e5453.

Kim, J.Y.., Alamsjah, M.A., Hamada, A., Fujita,Y. and Ishibashi, F. (2006) Algicidal diterpenes from the brown alga Dictyota dichotoma. Biosci. Biotechnol. Biochem. 70, 2571-2574.

Laib, E. and Leghouchi, E. (2012) Cd, Cr, Cu, Pb and Zn concentrations in Ulva lactuca, Codium fragile, Jania rubens, and Dictyota dichotoma from Rabta Bay, Jijel (Algeria). Environ. Monit. Assess. 184, 1711-1718.

Mohamed, N. A., Ibraheem, I.B. and Mohamed, S.H. (2006) Seasonal occurrence and variation in macroalgal populations in Hurghada, Safaga and Qusier Coasts of Red-Sea. Egypt.Proc. ${ }^{\text {th }}$ Int. Con. Biol. Sci. (Botany), pp.189-197.

Morton, L.H.G., Greenway, D.L.A., Gaylarde, C.C. and Surman, S.B. (1998) Consideration of some implications of the resistance of biofilms to biocides. Int. Biodeter. Biodegr. 41, 247-59.

Neu, H.C. (1992) The crisis in antibiotic resistance. Science, 257,1064-73

Nikaido, H. (2003) Molecular basis of bacterial outer membrane permeability revisited. Microbiology and Molecular Biology Reviews, 67(4), 593-656.

Othmani, A., Bouzidi, N.,Viano, Y., Alliche, Z., Seridi, H., Blachem, Y., El Hattab, M., Briand, J. and Culioli, G. (2014) Anti-microfouling properties of compounds isolated from several Mediterranean Dictyota spp. J. Appl. Phycol. 26,1573-1584.

Pereira, H., Barreira, L., Figueiredo, F., Custódio, L., Vizetto-Duarte, C., Polo, C., Re šek, E., 
Engelen, A. and Varela, J. (2012) Polyunsaturated fatty acidsof marine macroalgae: potential for nutritional and pharmaceutical applications. Mar. Drugs, 10,1920-1935.

Priyadharshini, B., Prabhu, S. and Ran, S.S. (2011) Antimicrobial activity and hemolytic activity of seaweed extracts Ulva fasciata (Delile 1813) from Mandapam, Southeast coast of India. In Asian Pacific Journal of Tropical Biomedicine, 1, S38-S39.

Rasher, D.B. and Hay, M.E. (2010) Chemically rich seaweeds poison corals when not controlled by herbivores. Proc. Natl. Acad.Sci. 107, 9683-9688

Rasher, D.B., Stout, E.P., Engel, S., Kubanek, J. and Hay, M.E. (2011) Macroalgal terpenes function asallelopathic agents agains tree fcorals.Proc.Natl. Acad.Sci. 108,17726-17731

Sakineh, M., Morteza,Y., Mohamad, A. and Esmaeili, R. (2015) Cytotoxicity and antimicrobial activity of marine macro algae (Dictyotaceae and Ulvaceae) from the Persian Gulf Springer Science+Business Media Dordrecht, 68(5), 1717-1726.

Salem, W., Galal, H. and Nasr El-deen, F. (2011) Screening for antibacterial activities in some marine algae from the red sea (Hurghada, Egypt). Afr. J. Microbiol. Res. 5, 2160-7.

Shridhar, D., Mahajan, G., Kamat, V., Naik, C., Parab, R. and Thakur, N. (2009) Antibacterial activity of 2-(2, 4-dibromophenoxy)-4,6-dibromophenol from Dysidea granulosa. MarDrugs, 7, 464-71.

Stirk, W.A., Reinecke, D.L. and Staden, V. (2007)
Seasonal variation in antifungal, antibacterial and acetylcholine esterase activity in seven South African seaweeds. Journal of Applied Phycology, 19, 271-276.

Tringali, C., Piattelli, M., Nicolosi, G. and Hostettmann, K. (1986) Molluscicidal and antifungal activity of diterpenoids from brown algae of the family Dictyotaceae. Planta Med. 5, 404-406

Vallinayagam, K., Arumugam, R., Kannan, R., Thirumaran, G. and Anantharaman, P. (2009) Antibacterial activity of some selected seaweeds from Pudumadam Coastal regions. Global J. Pharmacol. 3(1), 50-52.

Viano, Y., Bonhomme, D., Camps, M., Briand, J.F., Ortalo-Magné, A., Blache, Y., Piovetti, L. and Culioli, G. (2009) Diterpenoids from the Mediterranean brown alga Dictyota sp. evaluated as antifouling substances against marine bacterial biofilm. J. Nat. Prod. 72,1299-1304.

Voidarou, C., Alexopoulos, A., Plessas, S., Karapanou, A., Mantzourani, I. and Stavropoulou, E. (2011) Antibacterial activity of different honeys against pathogenic bacteria. Anaerobe. 17, 375-9.

Zielinski, A.A.F., Braga, C.M., Demiate, I.M., Beltrame, F.L., Nogueira, A. and Wosiacki, G. (2014) Development and optimization of a HPLCRI method for the determination of major sugars in apple juice and evaluation of the effect of the ripening stage. Food Sci. Technol, Campinas. 34(1), 38-43. 
التأثير المثبط لمستخلص الطحلب البني ديكتبوتاديكوتوما للنمو الميكروبي

إبراهيم برعى محمد إبراهيم، نيفين عبدالرؤف، هناء محمود محمد*، رحاب يحيي فصيحي و سهام موسي

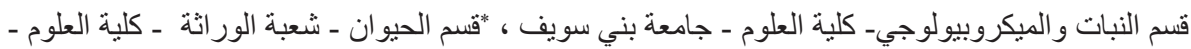

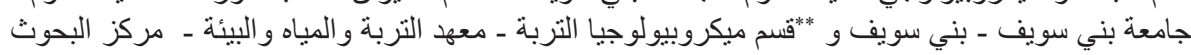

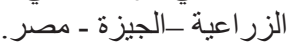

في هذا البحث تم جمع الطحلب البني ديكتيوتا ديكوتوما من ساحل البحر الأحمر بدينة سفاجا، مصر (أبريل

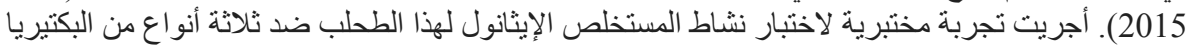

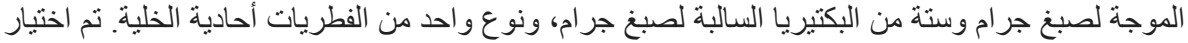

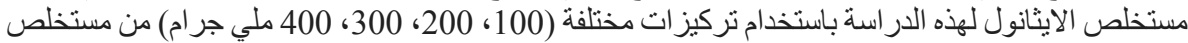

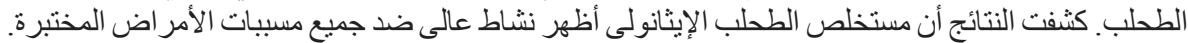

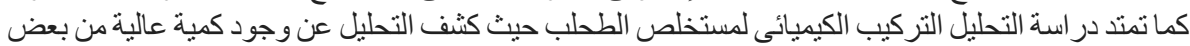

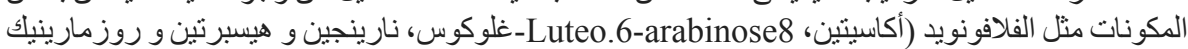

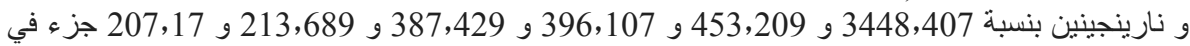

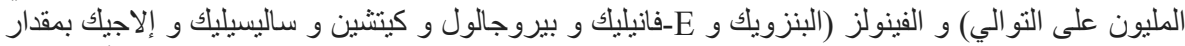

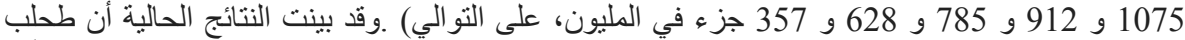
ديكتيوتا ديكوتوما يستحق تعميق الدراسة عليه حيث يمكن أن يُستخدم كمصدر طبيعي للمو اد النشطة بيولو لئياً. 